Article

\title{
Anthropogenic Influences on Environmental Changes of Lake Bosten, the Largest Inland Freshwater Lake in China
}

\author{
Wen Liu 1,2,3 $\mathbb{D}$, Long Ma 1,2,3,*(D) and Jilili Abuduwaili 1,2,3 \\ 1 State Key Laboratory of Desert and Oasis Ecology, Xinjiang Institute of Ecology and Geography, Chinese \\ Academy of Sciences, Urumqi 830011, China; liuwen@ms.xjb.ac.cn (W.L.); jilil@ms.xjb.ac.cn (J.A.) \\ 2 Research Center for Ecology and Environment of Central Asia, Chinese Academy of Sciences, \\ Urumqi 830011, China \\ 3 University of Chinese Academy of Sciences, Beijing 10049, China \\ * Correspondence: malong@ms.xjb.ac.cn
}

Received: 28 November 2019; Accepted: 16 January 2020; Published: 18 January 2020

\begin{abstract}
A short lacustrine sediment core $(41 \mathrm{~cm})$ from Lake Bosten in arid central Asia was used to investigate the environmental changes that occurred in the past $\approx 150$ years based on the superposition of climate and anthropogenic factors. Geochemical elements, total organic carbon (TOC) and nitrogen $(\mathrm{TN})$, and stable isotope data $\left(\delta^{13} \mathrm{C}_{\mathrm{org}}\right.$ and $\left.\delta^{15} \mathrm{~N}\right)$ were used to identify abnormal environmental changes. The average $\mathrm{C} / \mathrm{N}$ ratio in the sediments of Lake Bosten suggested that the organic matter in lake sediments was mainly from aquatic plants. The $\delta^{13} \mathrm{C}_{\text {org }}$ and $\delta^{15} \mathrm{~N}$ in the lake sediments mainly reflect changes in the structure of the lake's ecosystem. Before the 1960s, the primary productivity of the lake was relatively low with a relatively stable lake water environment. From the 1960s to the mid-1980s, the lake's ecosystem was closely related to a significant decline in water levels caused by human activities and an increase in salinity. From the late 1980 s to $\approx 2000$, the aquatic plant structure of Lake Bosten did not change significantly. After 2000, the upper part of the sedimentary record suggested enhanced productivity due to urban and industrial development in the catchment area. However, sedimentary perspectives of the responses of different environmental proxies in sediments to human activities were anisochronous, and the increasing heavy metal $(\mathrm{Pb}$ and $\mathrm{Cu})$ and P accumulations appeared in 1970, reflecting heightened human impacts. Through the comparison between the Aral Sea and Lake Bosten, it was inferred that, under the intervention of human activities, the lake experienced a completely different evolution trend. Humans, as geological agents, should protect our living environment while satisfying social development. The results will provide an important supplement to a large spatial scale study of the influences of human activities on the environment in Central Asia, which also has some significant implications for the protection of the ecological environment and the realization of sustainable development in arid regions.
\end{abstract}

Keywords: environmental consequences; organic geochemical proxies; lake sediment; Lake Bosten; anthropogenic influence; Central Asia

\section{Introduction}

As one of the most vulnerable terrestrial ecosystems, the arid regions of Central Asia are intertwined by the westerly circulation, the Arctic Ocean airflow, and the Indian Monsoon Current, making them sensitive to global change [1,2]. Humans, as geological agents $[3,4]$, have profoundly changed the process of environmental evolution. Due to the combined effects of climate change and human activities, the regional land surface processes are undergoing extensive changes [5], which are illustrated by changes in the hydrological processes and the resulting ecological and environmental 
effects [6,7]. Lakes in Central Asia are an important part of the regional water resource system [8]. They play an important supporting role in maintaining the balance between regional ecosystems. In addition, lakes and terrestrial ecosystems are undergoing extensive material and energy exchanges, and we can use changes in the lake environments of Central Asia and the factors influencing them to investigate regional environmental changes and improve regional ecological environmental protection plans. The study in this paper will also provide an opportunity to investigate the interaction between human activities and climate change in basins.

With the intensification of human influence on the natural environment and the gradual dominance of surface ecological processes by human activities, the earth has entered the "Anthropocene" epoch, and the study of human-Earth system coupling has become an important approach to achieve sustainable development [9-11]. Lake sediments act as a sink for terrigenous material, recording the history of human-environment interactions [12], which can be used to reconstruct climate change and environmental evolution at different time scales and assess the impacts of human activities on ecosystems [13]. Due to high sedimentation rates, the lake sediments in Central Asia provide important information for studying climatic and environmental changes $[14,15]$. Previous studies have shown that lacustrine sediments in arid areas can be used to investigate environmental evolution. These methods have been applied in research on lake sediments from Central Asia, especially for evolutionary events that occurred in the last millennium [16-20]. The existing lake sedimentary records show that the impact of human activities on the environment in arid areas has been significantly enhanced since the 1950s [21,22]. However, existing studies focused on the northern part of Tian Shan Mountains-for example, Lake Ebinur [22], Lake Sayram [23] and Lake Chaiwopu [24]—while research on the record of human activities in the southern part of Tianshan has not been carried out yet.

The region of Lake Bosten is of great significance to studies concerning environmental changes in regions dominated by the westerlies [25]. Intense water demand along the river has resulted in extensive environmental changes to the lake during the last few decades [26]. With regard to Lake Bosten, changes to the modern lake environment including changes in water quality and quantity [27-31] and surface lake sediments [32-36] are of great interest. Some studies have also discussed paleo-environmental changes over long time scales $[26,34,37,38]$. The spatial distribution of the organic carbon in the surface sediments [39] and carbon burial over the past century have also been used to reveal the important role in the terrestrial carbon cycle [40]. In addition, modern surface sediments of Lake Bosten were studied over recent decades [32-36]; however, the ecological and environmental response to climate change and intensified human activities have not been studied.

This paper focuses on the response of the lake environment to human interventions and climate change and its spatial variation in the arid region of Central Asia. In this paper, based on analysis of the organic proxies and geochemical elements in Lake Bosten core sediments at the no-instrumental recording period, environmental changes over the past 150 years will be elucidated under the impact of human activities, and the differences in the response of different environmental proxy indicators of lake sediments to human activities will be revealed. The results will provide an important supplement to the large-scale studies of the impacts of human activities on the environment. In addition, the instrumental records show that lake hydrology in arid areas of Central Asia has changed significantly in the past half century—for example, the Aral Sea [41], Lake Bosten [42], Lake Issyk-Kul [43], and Lake Ebinur [44]. It is also necessary to clarify the responses of human activities to sediments and whether human activities have had some impacts on lake ecosystems. Finally, through a spatial comparison, this paper will investigate the response of lake environments to human interventions in arid Central Asia.

\section{Materials and Methods}

\subsection{Geographic Setting}

The Lake Bosten watershed is located between the Tian Shan Mountains and the Taklamakan Desert (Figure 1). The Lake Bosten watershed has an area of $45,000 \mathrm{~km}^{2}$ and has a typical arid 
climate [45]. The total annual precipitation is only $76.1 \mathrm{~mm}$, while evaporation is $2000 \mathrm{~mm} / \mathrm{year}$ [26]. In the 1960s, $1174.86 \mathrm{~km}^{2}$ of the watershed was covered by farmland; by the early $1990 \mathrm{~s}, 760.41 \mathrm{~km}^{2}$ of this area was covered by farmland [46]. There are six counties-Yanqi, Bohu, Hejing, Heshuo, Korla, and Yuli-in the Bosten watershed. Over the past 50 years, the economy has developed rapidly. The sums of several economic variables were calculated, including the year-end population, gross domestic product (GDP), total sown area for farm crops, and the number of industrial enterprises, to confirm the rapid growth in the region. For example, the GDP sharply increased from $5.6 \times 10^{6}$ Chinese Yuan (CNY, 1 USD = 6.9 CNY) in 1949 to $3.8 \times 10^{8} \mathrm{CNY}$ in 2004.
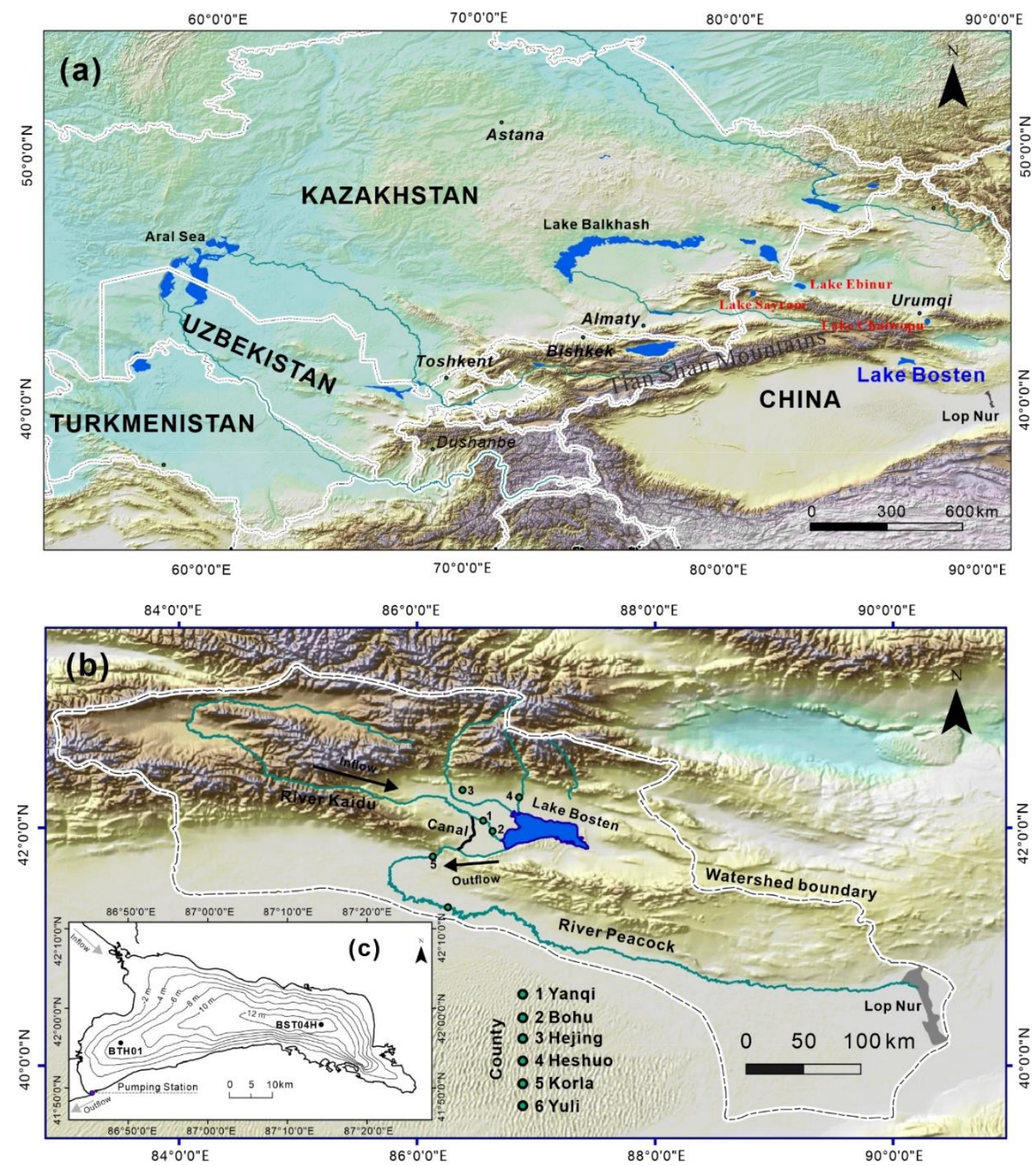

Figure 1. Geographic setting of Lake Bosten in Central Asia, and the location of the core. (a) Overview map of major lakes in Central Asia. (b) Map of Lake Bosten watershed. (c) Bathymetric map for Lake Bosten and the locations of sediment cores BTH01 and BST04H [45].

Lake Bosten was the largest freshwater body in north-western China and originates from the Kaidu River in the glaciated mountain ranges of Tian Shan; it is the source of the Peacock River (the source of Lop Nur) [47]. Lake Bosten is located at $1050 \mathrm{~m}$ above sea level and is $81 \mathrm{~km}$ long and $42 \mathrm{~km}$ wide, covering an surface area of $1005 \mathrm{~km}^{2}$ [48]. Lake Bosten has undergone significant changes over 
the past fifty years. For example, the water level of Bosten Lake varies significantly with fluctuations of $5 \mathrm{~m}$, and the salinity has increased from $\approx 0.4 \mathrm{~g} / \mathrm{L}$ in 1958-1960 to $1.48 \mathrm{~g} / \mathrm{L}$ in 2008 [48,49].

According to the distribution of aquatic plants in the lake [50], the most widely distributed species of aquatic plants are Ceratophyllum demersum, followed by Myriophyllum, Potamogetoncrispus, Potamogeton, and Najas marina. The submerged plant species are mainly present in the littoral zone (1-2 $\mathrm{m}$ water depth) and sub-littoral zone (5-6 $\mathrm{m}$ depth), while the deep-water areas have no submerged plants.

\subsection{Sediment Sampling and Laboratory Analysis}

In June 2016, a gravity core sediment sampler (Uwitec, Mondsee, Austria), fitted with a $60 \mathrm{~mm}$ internal diameter Perspex tube was used to extract a $41 \mathrm{~cm}$ long sediment core $\left(41^{\circ} 55.665^{\prime} \mathrm{N}, 86^{\circ} 49.078^{\prime}\right.$ E) at a depth of $7.0 \mathrm{~m}$ in Lake Bosten (Figure 1c). According to the site description, the core consists of fine silt with a dark brown colour. Since no significant sedimentary events were found, the core was evenly sliced at $1 \mathrm{~cm}$ intervals in situ, and the samples were freeze-dried for laboratory analysis. All the analyses were conducted at the analytical centre of the State Key Laboratory of Lake Science and Environment, Nanjing, China.

A part of each sample of dried sediment was analyzed for ${ }^{210} \mathrm{~Pb},{ }^{226} \mathrm{Ra}$, and ${ }^{137} \mathrm{Cs}$ using an EG\&G Ortec Gamma Spectrometer (HPGe GWL-120-15, EG\&G/ORTEC, Tennessee, USA) [51]. The activity of ${ }^{226} \mathrm{Ra}$ in the lake sediments was evaluated by averaging the activities of ${ }^{214} \mathrm{~Pb}(295 \mathrm{keV}, 352 \mathrm{keV})$ and ${ }^{214} \mathrm{Bi}(609 \mathrm{keV})$. The total ${ }^{210} \mathrm{~Pb}$ was determined via its emissions at $46.5 \mathrm{keV}$, and the total ${ }^{137} \mathrm{Cs}$ was determined via its emissions at $662 \mathrm{keV}$. The determination of total organic carbon (TOC) and total nitrogen (TN) were performed using a CE-440 elemental analyser (EAI Company, Lexington, KY, USA) [52]. The levels of $\delta^{13} \mathrm{C}$ and $\delta^{15} \mathrm{~N}$ were analyzed using a Finnigan-MAT 251 isotope ratio mass spectrometer (Finnigan MAT, Bremen, Germany) [21]. These levels are expressed in standard per mil (\%o) notation relative to the international standards, Vienna Pee Dee Belemnite and atmospheric $\mathrm{N}$, respectively. The average reproducibility for $\delta^{13} \mathrm{C}$ and $\delta^{15} \mathrm{~N}$ were $0.05 \%$ ond $0.25 \%$, respectively. Aluminium ( $\mathrm{Al})$, iron ( $\mathrm{Fe})$, and zinc $(\mathrm{Zn})$ were analysed using a Leeman Labs Profile Inductively Coupled Plasma Spectrometer (ICP-AES, Prodigy, Teledyne Leeman Labs, Hudson NH, USA) and inductively coupled plasma mass spectrometry (ICP-MS, Agilent 7700x; Agilent Technologies, Santa Clara, USA) for copper $(\mathrm{Cu})$ and lead $(\mathrm{Pb})$. The correlation coefficient and its matrix were used to reflect the relationship between elements $(\mathrm{Al}, \mathrm{Fe}, \mathrm{Zn}, \mathrm{Cu}$, and $\mathrm{Pb})$.

\subsection{Data Collection for Instrumental Records}

In order to study the differences of the impact of human activities on nature under the same climate change background, we compared the measured records of Bosten Lake and the Aral Sea. Dynamics of fish catches in the Aral Sea were taken from the reference [53]. Annual precipitation (mm) was recorded at the Yanqi weather station (location in Figure 1). Precipitation data within the Aral Sea drainage basin were referred to in reference [54]. The data for Lake Bosten water volume and river inflow to Lake Bosten were recorded in reference [55]. The data of Amu Darya inflows to the Aral Sea were from reference [56], and the water volume of the Aral Sea were recorded in reference [41].

\section{Results and Discussions}

\subsection{The Chronology of the Bosten Lake Sediment Core}

The specific activity of the excess ${ }^{210} \mathrm{~Pb}$ was obtained by measuring the amount of ${ }^{210} \mathrm{~Pb}$ and

${ }^{226} \mathrm{Ra}$ within a layer [57]. ${ }^{210} \mathrm{~Pb}$ and ${ }^{226} \mathrm{Ra}$ were in equilibrium at $39 \mathrm{~cm}$, and the chronology of the Lake Bosten sediment was established using the constant rate of supply (CRS) model [58] supported by ${ }^{210} \mathrm{~Pb}_{\mathrm{ex}}$ data $\left({ }^{210} \mathrm{~Pb}\right.$ ex $\left.={ }^{210} \mathrm{~Pb}-{ }^{226} \mathrm{Ra}\right)$.

The characteristics of the specific activity of ${ }^{137} \mathrm{Cs}$ with depth in lake sediment cores are shown in a previously published paper [57]. There has been significant measurable global fallout of ${ }^{137} \mathrm{Cs}$ since 
1954 [59], and this fallout marked the Lake Bosten sediment core at $29 \mathrm{~cm}$, which is perfectly consistent with the ${ }^{210} \mathrm{~Pb}$ dating. In general, there should be a global ${ }^{137} \mathrm{Cs}$ fallout peak at 1963 ; however, the Lake Bosten watershed is a unique nuclear test zone in China. The core sediments recorded the local bomb tests with a peak in 1976 [45], which is in good agreement with the date inferred from ${ }^{210} \mathrm{~Pb}$.

\subsection{Organic Matter Proxies and Their Reponses to Anthropogenic Influences}

The average TOC is $2.7 \%$, with a maximum of $3.5 \%$ and a minimum of $2.1 \%$. From the baseline to 1960 , there is an increasing trend for organic carbon content. Then, there is a decrease until 1980 with a minimum value of $2.1 \%$. Since 1980 , the organic carbon content gradually increases again. The average $\mathrm{TN}$ of the sediments is $0.53 \%$, with a maximum of $0.75 \%$ and a minimum of $0.40 \%$. There are obvious similarities between TOC and TN (Figure 2).

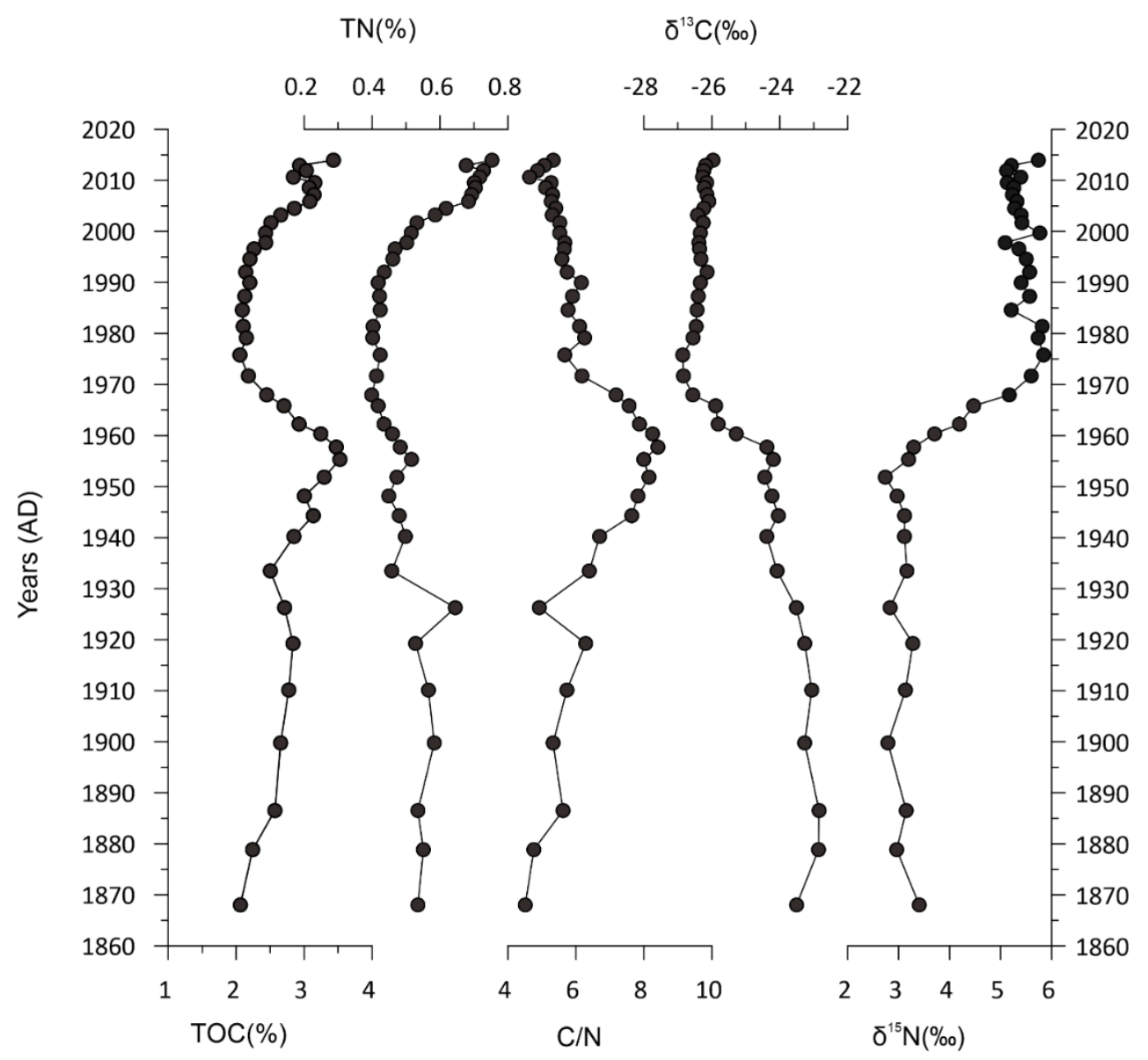

Figure 2. Variation in organic matter indices: total organic carbon (TOC), total nitrogen (TN), carbon/nitrogen ratios $(\mathrm{C} / \mathrm{N})$, stable carbon $\left(\delta^{13} \mathrm{C}\right)$ and stable nitrogen $\left(\delta^{15} \mathrm{~N}\right)$ ratios, for the Lake Bosten sediment core BTH01. There are two discontinuities at ca. 1960 and 2005.

The organic materials, TOC, and TN in the lake sediments are mainly controlled by the initial productivity of the lake and by the input of terrigenous organic debris [60,61]. Different sources of organic matter have different $\mathrm{C} / \mathrm{N}$ ratios-for example, the TOC/TN ratio. Aquatic phytoplankton are mainly rich in protein and organic nitrogen, so the $\mathrm{C} / \mathrm{N}$ ratio is low (from four to 10). Terrestrial vascular plants are composed mainly of lignin and cellulose and lack nitrogen; thus, the $\mathrm{C} / \mathrm{N}$ value of terrigenous organic matter is usually 20-30 [62]. The $\mathrm{C} / \mathrm{N}$ ratio of lake sediments has been widely used to distinguish the source of sedimentary organic matter $[63,64]$. When the $\mathrm{C} / \mathrm{N}$ ratio is less than 10 , the organic matter is derived from aquatic plants; when the $\mathrm{C} / \mathrm{N}$ ratio is greater than 20 , the organic matter is derived from terrestrial plants. Therefore, the $\mathrm{C} / \mathrm{N}$ ratio can be used to determine the source 
of the organic matter during the formation of sedimentary sequences. The average $\mathrm{C} / \mathrm{N}$ ratio in the sediments of Lake Bosten is 6.1. The maximum value is 8.4, recorded ca. 1960. The results suggested the organic matter was mainly from aquatic plants and inferred the initial productivity in the lake. The variations in the organic geochemical proxies of the core sediments from Lake Bosten are shown in Figure 2. The average TOC is $2.7 \%$, with a maximum of $3.5 \%$ and a minimum of $2.1 \%$. From the baseline to 1960, there is an increasing trend for organic carbon content. Then, there is a significant decrease until 1980, with a minimum value of $2.1 \%$. Since 1980, the organic carbon content gradually increases again. The average TN of the sediments is $0.53 \%$, with a maximum of $0.75 \%$ and a minimum value of $0.40 \%$. There are obvious similarities between TOC and TN.

The $\delta^{13} C_{\text {org }}$ values vary from $-22.84 \%$ o to $-26.86 \%$. From 1868 to 1960 , the isotopic values show a slight increase. From 1960, the organic carbon isotopic values are negative, with an average value of $-26.31 \%$, which is contrary to the trend of nitrogen isotope $\delta^{15} \mathrm{~N}$. From 1960 , the organic carbon isotopic values are negative, with an average value of $-26.31 \%$. The $\delta^{13} \mathrm{C}_{\text {org }}$ values in lake sediments are mainly determined by the source of the organic matter in the lake sediments, which is generally influenced by a mixture of terrestrial plants, aquatic plants, and plankton [52]. In addition, the $\delta^{13} \mathrm{C}_{\text {org }}$ content is affected by the lake chemistry ( $\mathrm{pH}$, water hardness, etc.), primary lake productivity, atmospheric carbon dioxide concentration, watershed hydrology characteristics, regional natural environment, sedimentary environment, and sedimentation [65]. Based on the $\mathrm{C} / \mathrm{N}$ ratio, the organic matter in the sediments from Lake Bosten is mainly derived from lacustrine aquatic plants. Aquatic plants can be divided into floating plants and submerged plants based on the source of the $\mathrm{CO}_{2}$ they use for photosynthesis. Floating plants include emergent plants, phytoplankton, and floating-leaf plants. The $\delta^{13} \mathrm{C}$ values of floating plants are close to the $\delta^{13} \mathrm{C}$ values of terrestrial $C_{3}$ plants, usually ranging from $-22 \%$ o to $-33 \%$ o [66]. Photosynthesis and the growth of submerged plants are affected by the water bodies they grow in. Restrictions in the supply of dissolved $\mathrm{CO}_{2}$ will cause the plants to use $\mathrm{HCO}_{3}$ for their growth. Under normal temperature conditions, the value of $\delta^{13} \mathrm{C}$ in $\mathrm{HCO}_{3}$ is greater than that of dissolved $\delta^{13} \mathrm{C}\left(\mathrm{CO}_{2}\right)$ by $8.8 \%$ o to $11.5 \%$, resulting in positive $\delta^{13} \mathrm{C}$ values for submerged plants $(-20 \%$ o to $-12 \%$ o) [66]. In addition, as the amount of photosynthesis continues to increase, more ${ }^{12} \mathrm{C}$ is selectively removed from the surface waters of the lake, which can result in the aquatic plants being enriched in ${ }^{13} \mathrm{C}$, causing the $\delta^{13} \mathrm{C}$ content of the aquatic organic matter to increase.

From 1868 to 1960, the nitrogen isotope values are low. From 1960 to 1980, the nitrogen isotope values increase significantly. From 1980, the nitrogen isotope values are high, and the variations in organic carbon and nitrogen isotopic values have a significant correlation coefficient $R^{2}=0.953(p<0.01)$. The soil nitrogen in the catchment was derived from atmospheric nitrogen fixed by nitrogen-fixing bacteria. The $\delta^{15} \mathrm{~N}$ value of the soil is similar to the atmospheric nitrogen $\delta^{15} \mathrm{~N}$ value $(0 \%$ o), which was much smaller than the $\delta^{15} \mathrm{~N}$ value of the dissolved inorganic nitrogen (DIN) in the lake water [66]. Therefore, if there is an increase in precipitation in the lake watershed, the lake water's DIN reservoir will be depleted in ${ }^{15} \mathrm{~N}$, resulting in lower ${ }^{15} \mathrm{~N}$ values for aquatic plants and a decrease in $\delta^{15} \mathrm{~N}$ in aquatic organisms. However, this decrease in the DIN concentration of the lake water decreases fractionation, which results in the aquatic plants being enriched in ${ }^{15} \mathrm{~N}$, causing the $\delta^{15} \mathrm{~N}$ value of the aquatic organic matter to increase. Nitrification and denitrification also significantly enrich the ${ }^{15} \mathrm{~N}$ of the lake's DIN reservoir, resulting in the enrichment of ${ }^{15} \mathrm{~N}$ in aquatic plants and an increase in the $\delta^{15} \mathrm{~N}$ value of aquatic organisms [67].

The climate was cold and humid during the little ice age (LIA) (ca. 1500-1900) in this region [45]. From the end of the LIA to 1960, as the global climate warmed, the primary productivity of the lake increased. There was no significant sudden change in $\delta^{13} \mathrm{C}$ and $\delta^{15} \mathrm{~N}$ levels during this period, indicating that the lake environment would have been relatively stable. However, there is a discontinuity at 1960 (Figure 2). Since 1960, the TOC, TN and $\delta^{13} \mathrm{C}$ levels significantly decreased, reflecting a significant decrease in the primary productivity of the lake. This decrease in productivity is closely related to the significant decline in water level and increased water salinity caused by enhanced water demands (Figure 3). As the lake's water level decreased, sediment nitrification was enhanced (Figure 3). 


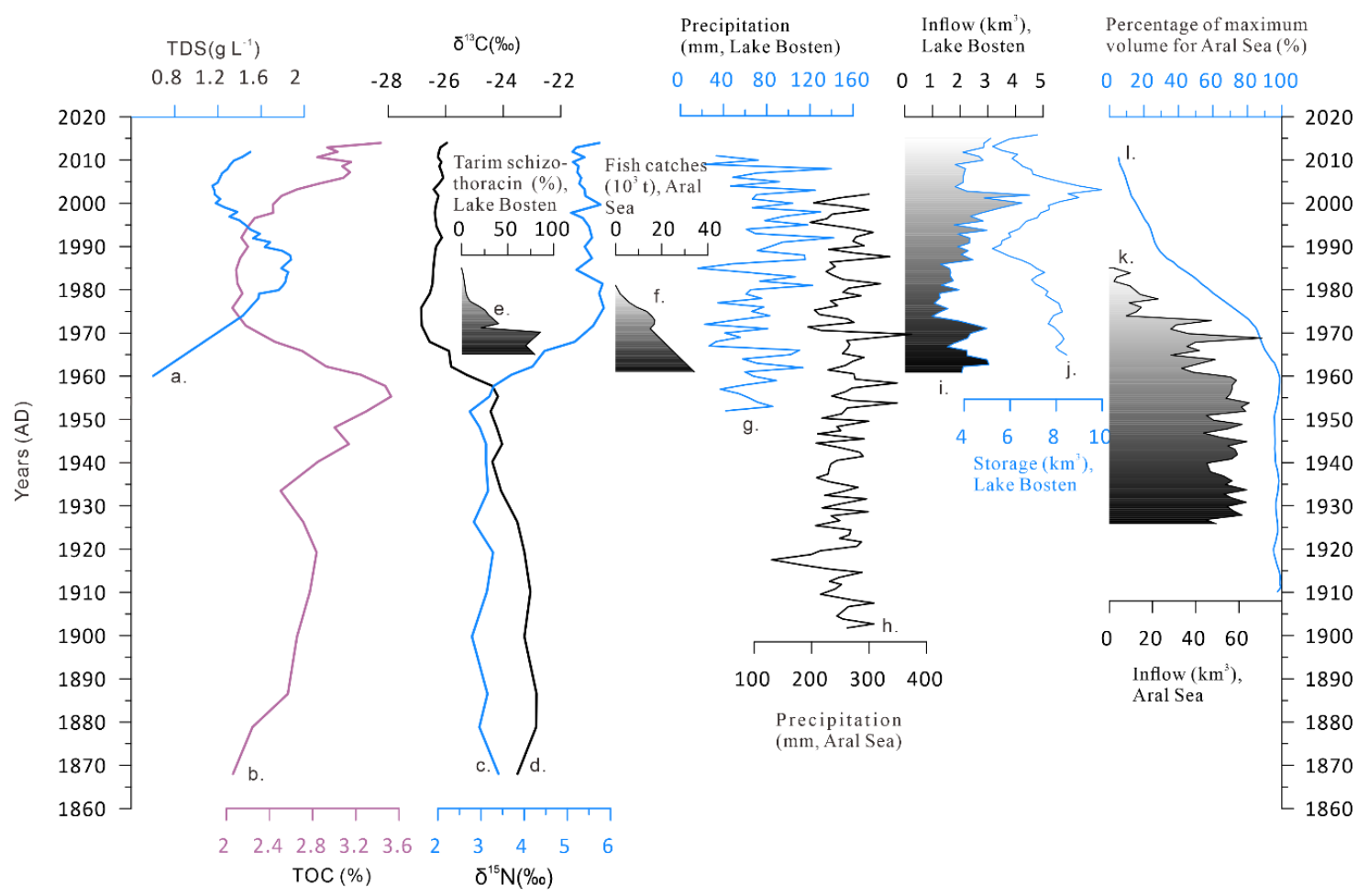

Figure 3. Comparative study of regional responses to human activity. (a) Total dissolved solids (TDS) [55]; (b) total organic carbon (TOC); (c) nitrogen ${ }^{15} \mathrm{~N}$ value $\left(\delta^{15} \mathrm{~N}\right)$; (d) organic carbon ${ }^{13} \mathrm{C}$ value $\left(\delta^{13} \mathrm{C}\right)$; (e) Tarim schizothoracin in the total catch percentage; (f) dynamics of fish catches in Aral Sea [53]; (g) annual precipitation ( $\mathrm{mm}$ ) recorded at the Yanqi weather station (location in Figure 1); (h) precipitation data within the Aral Sea drainage basin [54].(i) variations in inflow to Lake Bosten [55]; (j) Lake Bosten water volume $\left(\mathrm{km}^{3}\right)$; (k) Amu Darya inflows to the Aral Sea [56]; (l) percentage of the maximum volume for Aral Sea [41]. For the sake of timing comparison, all curves have the same y-coordinates.

\subsection{Geochemical Elements and Their Reponses to Anthropogenic Influences}

Elemental contents are shown in Figure 4. The maximum value of $\mathrm{Al}$ is $37.14 \mathrm{~g} \mathrm{~kg}^{-1}$, and the minimum value is $27.03 \mathrm{~g} \mathrm{~kg}^{-1}$. The concentration of $\mathrm{Al}$ was very similar to that of $\mathrm{Fe}$ (maximum is $19.05 \mathrm{~g} \mathrm{~kg}^{-1}$ and minimum is $14.13 \mathrm{~g} \mathrm{~kg}^{-1}$ ). The elements $\mathrm{Pb}$, and $\mathrm{Cu}$ have a generally consistent trend. The maximum and minimum values of $\mathrm{Pb}$ were $13.75 \mathrm{mg} \mathrm{kg}^{-1}$ are $7.92 \mathrm{mg} \mathrm{kg}^{-1}$, respectively. There is also same variation in trends among the $\mathrm{Pb}$ and $\mathrm{Cu}$ (maximum is $16.82 \mathrm{mg} \mathrm{kg}^{-1}$ and minimum is $11.58 \mathrm{mg} \mathrm{kg}^{-1}$ ).

Human activities have had an important influence on the source of terrigenous clastic materials in the lacustrine sediments of Lake Bosten. From the variation trend of the elements (Figure 4), the geochemical changes were obviously different before and after 1970. The vertical distributions of $\mathrm{Pb}$ and $\mathrm{Cu}$ mainly increased from 1970 until the present. In addition, the decrease of $\mathrm{Pb}$ content can be observed in the upper sediment layers (from $\approx 2005$ ). At Stage A (since 1970), the potentially toxic elements $(\mathrm{Pb}$ and $\mathrm{Cu}$ ) have negative correlations with $\mathrm{Al}$ and $\mathrm{Fe}$ (Figure 5). At Stage B (from 1868 to 1970), there are significant correlations among all elements, which indicated the same material sources. Generally, $\mathrm{Al}$ [68] and $\mathrm{Fe}$ [69] are from terrigenous clastic material, which is mainly derived from erosion/catchment soils. This phenomenon suggested that $\mathrm{Pb}$ and $\mathrm{Cu}$ have been influenced by anthropogenic contributions. Some of the elements are not only or predominately derived from the catchment (i.e., erosion) but also from atmospheric deposition. Furthermore, the decrease in $\mathrm{Pb}$ contents in the upper sediment layers (from $\approx 2005$ ) may show reduced atmospheric $\mathrm{Pb}$ pollution due to legal regulations. The studies of surface soils [70,71] and lake sediments [24] in arid regions of Central Asia show that heavy metals—such as $\mathrm{Pb}, \mathrm{Cu}$, and $\mathrm{Zn}$-generally represent pollution by 
human activities; however, $\mathrm{Zn}$ in the sediments of Lake Bosten has not shown signs of significant influence by human activities.

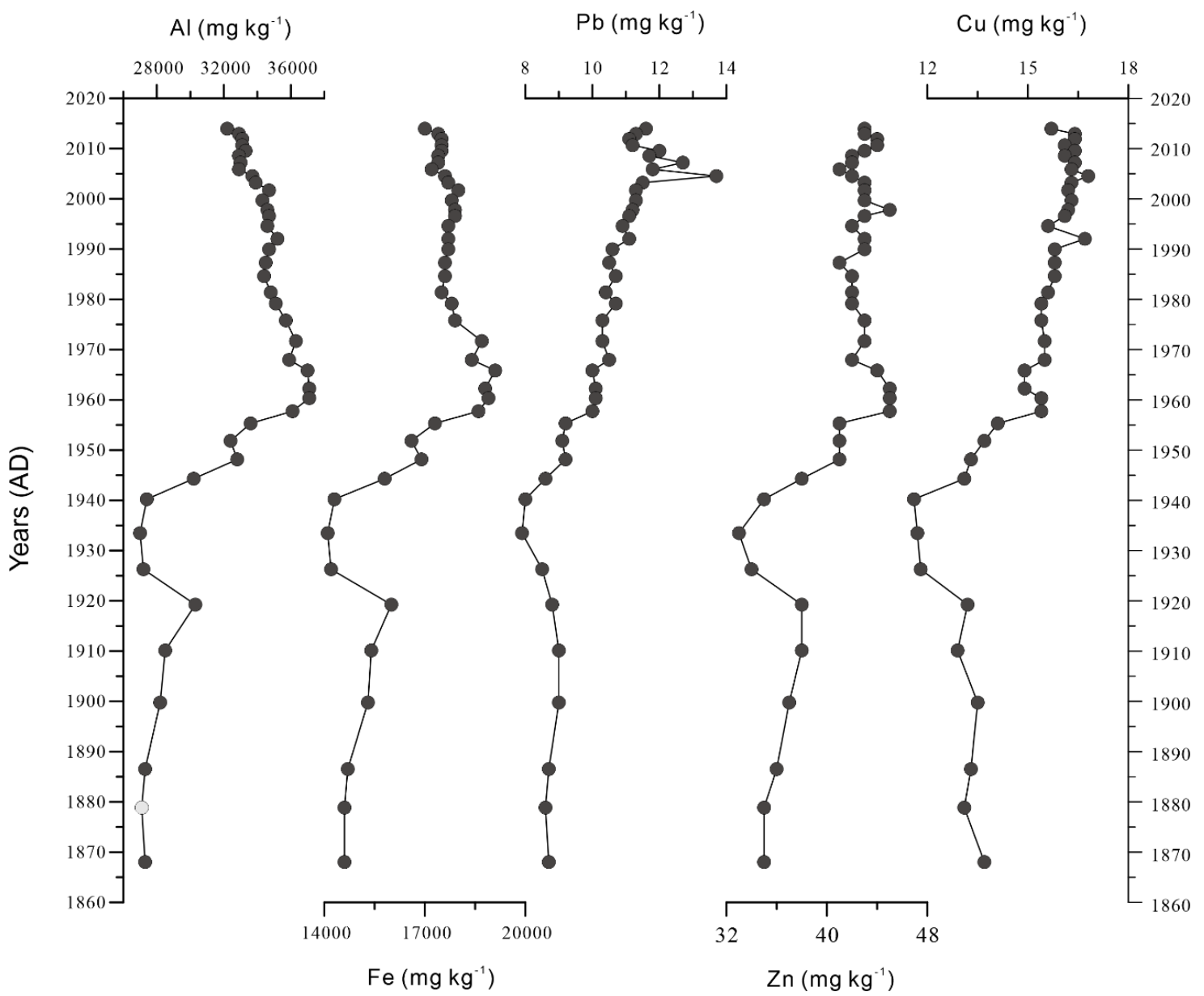

Figure 4. Sedimentary profiles of element contents: aluminium $(\mathrm{Al})$, iron $(\mathrm{Fe})$, lead $(\mathrm{Pb})$, zinc $(\mathrm{Zn})$, and copper $(\mathrm{Cu})$.

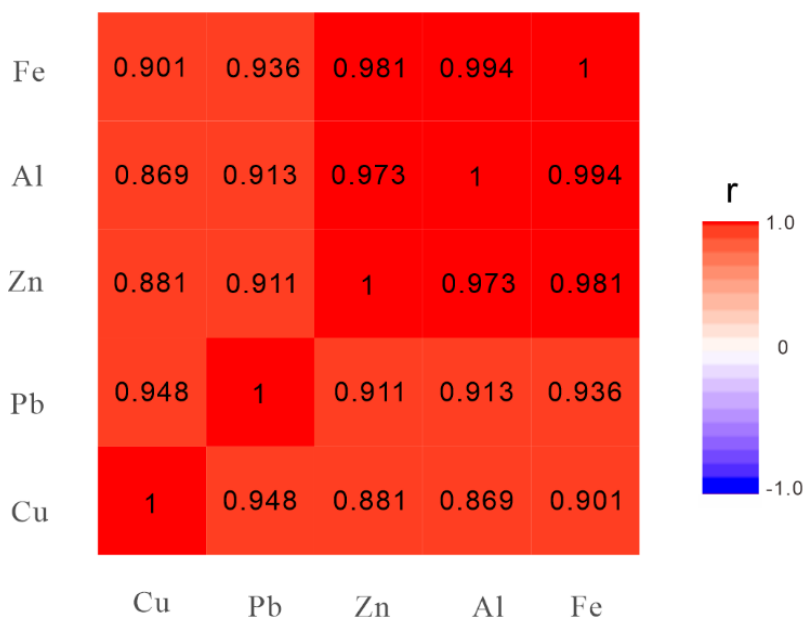

Stage A, Before 1970 AD

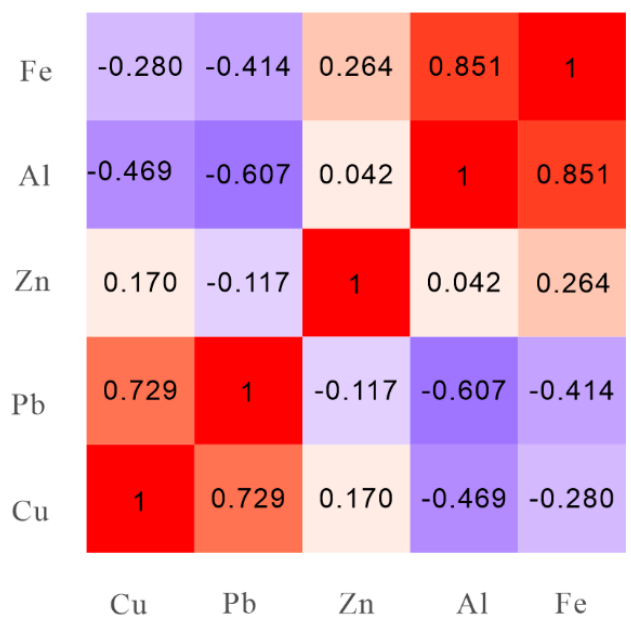

Stage B, After 1970 AD

Figure 5. Correlation matrix among the elements aluminium ( $\mathrm{Al})$, iron ( $\mathrm{Fe})$, lead $(\mathrm{Pb})$, zinc $(\mathrm{Zn})$, and copper (Cu), in different stages: left for stage A (since 1970) and right for stage B (from 1868 to 1970). 


\subsection{Regional Comparisions for Environmental Changes under Anthropogenic Influences in Central Asia}

In this paper, sedimentary perspectives of the responses of different environmental proxies in sediments to human activities were anisochronous. There was no significant sudden change in $\delta^{13} \mathrm{C}$ and $\delta^{15} \mathrm{~N}$ levels during this period, indicating that the lake environment would have been relatively stable. However, there is a discontinuity at 1960 (Figure 3). Since 1960, the TOC, TN, and $\delta^{13} \mathrm{C}$ levels significantly decreased, reflecting a significant decrease in the primary productivity of the lake. However, the study of the geochemical elements in sediments of Lake Bosten shows that the sedimentary sources had changed since the 1970s. Through the above discussion, it can be preliminarily concluded that sedimentological proxies are the perspectives of different environmental factors; however, the complexity of sedimentological responses allows a single proxy to imply the history of human activity and likely be limited by regional human conditions.

According to the existing studies on lake sediments in arid areas of Central Asia, the significant enhancement of human activities had led to significant changes in the sources of lake sediments. Among them, in the region of north Tianshan Mountains, important changes in sedimentary sources had taken place in the mid-1950s for Lake Ebinur (Figure 1) [22], for Lake Sayram (Figure 1) [23] in the 1960s, and for Lake Chaiwopu (Figure 1) in the 1950s [24], reflecting the temporal differences in the intensity of human activities in different regions. In terms of the changes in the impact of human activities on the lake ecosystem, although Ebinur Lake also experienced a significant contraction since the 1950s [44], which is consistent with the change of water level in Lake Bosten [72], the organic geochemistry proxies of Ebinur Lake, as a salt lake, maintained a certain stability [22]. However, the variation of organic carbon isotopes in the sediments of Lake Chaiwopu, a small shallow lake, is controlled by regional temperature [21]. In summary, due to the influence of different lake hydrological characteristics, the response of lake ecosystem to human activities and climate change shows great spatial variation.

According to instrumental records, the water level and water storage of Lake Bosten has declined since 2002, and the water salinity changed from falling to rising in 2004 [55] (Figure 3). The response of the lake ecosystem to different influencing factors is not consistent. In particular, the recent effect of the water salinity of Lake Bosten is much smaller than that of nutrient materials. In addition, the impact of human intervention on the lake ecosystem is also great. There are many similarities in the changes of the lake environments between the Aral Sea and Lake Bosten. By comparing the Aral Sea and Lake Bosten (Figure 3), it is found that the water storage of these two lakes continued to decline in the 1950s, and the water environment of both lakes was at its worst around the 1980s. In the 1980s, when the water salinity of the Aral Sea exceeded $18 \mathrm{~g} \mathrm{~L} / 1$, the Aral Sea had completely lost fishery [53], and there were only 1-5 fish species in the 1980s compared with 20 species in 1961 AD [73]. Tarim schizothoracin (Schizothorax biddulphi Günther) of Lake Bosten, which is only distributed in the Tarim Basin of the Xinjiang Autonomous Region in China [74], has also disappeared due to the high salinity of Lake Bosten (Figure 3) [49]. During this stage, the TOC and TN were both at minimum values in the sedimentary records of Lake Bosten, indicating that the lake's primary productivity was at its lowest value over the past 150 years.

To artificially intervene in the falling trend of lake water levels, the local government constructed a pumping station in the eastern part of Lake Bosten in 1983 to adjust the outflow to the Peacock River. Meanwhile, the decreased water consumption due to drip irrigation, mulching and other agricultural water-saving technologies, and enhanced watershed precipitation [55] has induced an increase in water levels since 1985 (Figure 3). Although precipitation in the Aral Sea has also increased since the late 1980s [54], the inflow of water entering the lake is consistently low [56], which has been due to prominent contradictions in the allocation of water resources between Central Asian countries and a lack of centralised and effective water resources utilization policies. The Aral Sea separated into northern (Small Aral Sea) and southern (Big Aral Sea) bodies in 1987 [75]. An earthen dike was constructed in 1992 to block the Syr Darya River inflow to the Big Aral Sea [76], and in 1996-1997, a very large dam was constructed to raise the level of the Small Aral Sea [77], which was a successful experiment and demonstration of stabilizing lower salinity and improving ecological and fishery 
conditions in the Small Aral Sea [78]. However, the Big Aral Sea is on the verge of disappearing; according to projections, the eastern part of the Big Aral Sea will basically disappear by 2025 [79]. Through the comparison between the Aral Sea and Lake Bosten, it was inferred that, under the intervention of human activities, the lake experienced a completely different evolution trend. Humans, as geologic agents $[3,4]$, should protect our living environment while satisfying social development.

\section{Conclusions}

The geochemical proxies in the lacustrine sediments of Lake Bosten in arid Central Asia provide an example of abnormal environmental changes under climate change and human activities over the past $\approx 150$ years, providing will provide an important supplement to large spatial scale studies of the influences of human activities on the environment in Central Asia.

(1) In this paper, sedimentary perspectives of the responses of different environmental proxies in sediments to human activities were anisochronous, and the complexity of sedimentological responses allows a single proxy to imply the history of human activity and is likely to be limited by regional human conditions.

(2) The average $\mathrm{C} / \mathrm{N}$ ratio in the sediments of Lake Bosten suggested that the organic matter in lake sediments mainly comes from aquatic plants. The stable isotope $\delta^{13} \mathrm{C}_{\text {org }}$ suggested changes in the composition of aquatic plants in lakes, which is closely related to the significant decline in the water levels and increased water salinity caused by enhanced water demands. The geochemical proxies of lake sediments did not respond to the changes since the late 1980s with increased water levels and improved water quality.

(3) Human activities have had an important influence on the source of terrigenous clastic materials in the lacustrine sediments of Lake Bosten. The heavy metals $(\mathrm{Cu}$ and $\mathrm{Pb})$ in Stage $\mathrm{A}$, that is, from 1970, are not correlated positively with $\mathrm{Al}$ (which is mainly derived from erosion/catchment soils), reflecting enhanced human impacts.

(4) According to the regional comparison, the period of significant enhancement of human activity recorded by the Bosten Lake sediment in the south of Tianshan is later than that in the north of Tianshan.

(5) In areas with similar natural backgrounds, the evolution of lakes (Lake Bosten and theAral Sea) have completely different forms under the intervention of human activities, reflecting that the influence mode and intensity of human activities must be controlled. This also has significant implications for the protection of the ecological environment and the realization of sustainable development in arid regions.

Author Contributions: Funding acquisition, L.M.; Investigation, W.L. and L.M.; Methodology, L.M.; Project administration, J.A.; Writing-original draft, W.L.; Writing—review and editing, L.M. and J.A. All authors have read and agreed to the published version of the manuscript.

Funding: This research was funded by the West Light Foundation of the Chinese Academy of Sciences, grant number 2016-QNXZ-A-4; the National Natural Science Foundation of China, grant number U1903115; and the Tianshan Youth Program of the Xinjiang Uygur Autonomous Region, China, grant number 2018Q008.

Acknowledgments: We acknowledge the West Light Foundation of Chinese Academy of Sciences and the Youth Innovation Promotion Association, CAS.

Conflicts of Interest: The authors declare no conflict of interest.

\section{References}

1. Lioubimtseva, E.; Henebry, G.M. Climate and environmental change in arid Central Asia: Impacts, vulnerability, and adaptations. J. Arid Environ. 2009, 73, 963-977. [CrossRef]

2. Chen, F.; Huang, W.; Jin, L.; Chen, J.; Wang, J. Spatiotemporal precipitation variations in the arid Central Asia in the context of global warming. Sci. China Ser. D Earth Sci. 2011, 54, 1812-1821. [CrossRef]

3. Wilkinson, B.H. Humans as geologic agents: A deep-time perspective. Geology 2005, 33, 161-164. [CrossRef] 
4. Price, S.J.; Ford, J.R.; Cooper, A.H.; Neal, C. Humans as major geological and geomorphological agents in the Anthropocene: The significance of artificial ground in Great Britain. Philos. Trans. R. Soc. A Math. Phys. Eng. Sci. 2011, 369, 1056-1084. [CrossRef]

5. Chen, X.; Bai, J.; Li, X.; Luo, G.; Li, J.; Li, B.L. Changes in land use/land cover and ecosystem services in Central Asia during 1990-2009. Curr. Opin. Environ. Sustain. 2013, 5, 116-127. [CrossRef]

6. Karthe, D.; Chalov, S.; Borchardt, D. Water resources and their management in central Asia in the early twenty first century: Status, challenges and future prospects. Environ. Earth Sci. 2015, 73, 487-499. [CrossRef]

7. Deng, H.; Chen, Y. Influences of recent climate change and human activities on water storage variations in Central Asia. J. Hydrol. 2017, 544, 46-57. [CrossRef]

8. Bai, J.; Chen, X.; Li, J.; Yang, L.; Fang, H. Changes in the area of inland lakes in arid regions of central Asia during the past 30 years. Environ. Monit. Assess. 2011, 178, 247-256. [CrossRef]

9. Lewis, S.L.; Maslin, M.A. Defining the Anthropocene. Nature 2015, 519, 171-180. [CrossRef]

10. Dirzo, R.; Young, H.S.; Galetti, M.; Ceballos, G.; Isaac, N.J.B.; Collen, B. Defaunation in the Anthropocene. Science 2014, 345, 401. [CrossRef]

11. Ruddiman, W.F. The Anthropocene. Annu. Rev. Earth Planet. Sci. 2013, 41, 45-68. [CrossRef]

12. Dearing, J.A.; Battarbee, R.W.; Dikau, R.; Larocque, I.; Oldfield, F. Human-environment interactions: Learning from the past. Reg. Environ. Chang. 2006, 6, 1-16. [CrossRef]

13. Mills, K.; Schillereff, D.; Saulnier-Talbot, É.; Gell, P.; Anderson, N.J.; Arnaud, F.; Dong, X.; Jones, M.; McGowan, S.; Massaferro, J.; et al. Deciphering long-term records of natural variability and human impact as recorded in lake sediments: A palaeolimnological puzzle. Wiley Interdiscip. Rev. Water 2017, 4, e1195. [CrossRef]

14. Wolff, C.; Plessen, B.; Dudashvilli, A.S.; Breitenbach, S.F.M.; Cheng, H.; Edwards, L.R.; Strecker, M.R. Precipitation evolution of Central Asia during the last 5000 years. Holocene 2016, 27, 142-154. [CrossRef]

15. Zhao, J.; An, C.-B.; Huang, Y.; Morrill, C.; Chen, F.-H. Contrasting early Holocene temperature variations between monsoonal East Asia and westerly dominated Central Asia. Quat. Sci. Rev. 2017, 178, 14-23. [CrossRef]

16. Chen, F.-H.; Chen, J.-H.; Holmes, J.; Boomer, I.; Austin, P.; Gates, J.B.; Wang, N.-L.; Brooks, S.J.; Zhang, J.-W. Moisture changes over the last millennium in arid central Asia: A review, synthesis and comparison with monsoon region. Quat. Sci. Rev. 2010, 29, 1055-1068. [CrossRef]

17. Li, Y.; Qiang, M.; Zhang, J.; Huang, X.; Zhou, A.; Chen, J.; Wang, G.; Zhao, Y. Hydroclimatic changes over the past 900 years documented by the sediments of Tiewaike Lake, Altai Mountains, Northwestern China. Quat. Int. 2017, 452, 91-101. [CrossRef]

18. Lan, J.; Xu, H.; Sheng, E.; Yu, K.; Wu, H.; Zhou, K.; Yan, D.; Ye, Y.; Wang, T. Climate changes reconstructed from a glacial lake in High Central Asia over the past two millennia. Quat. Int. 2017, 487, 43-53. [CrossRef]

19. Chiba, T.; Endo, K.; Sugai, T.; Haraguchi, T.; Kondo, R.; Kubota, J. Reconstruction of Lake Balkhash levels and precipitation/evaporation changes during the last 2000 years from fossil diatom assemblages. Quat. Int. 2016, 397, 330-341. [CrossRef]

20. Ma, L.; Wu, J.; Yu, H.; Zeng, H.; Abuduwaili, J. The Medieval Warm Period and the Little Ice Age from a sediment record of Lake Ebinur, northwest China. Boreas 2011, 40, 518-524. [CrossRef]

21. Ma, L.; Wu, J.; Abuduwaili, J. Climate and environmental changes over the past 150 years inferred from the sediments of Chaiwopu Lake, central Tianshan Mountains, northwest China. Int. J. Earth Sci. 2013, 102, 959-967. [CrossRef]

22. Liu, W.; Ma, L.; Wu, J.; Abuduwaili, J. Environmental variability and human activity over the past 140 years documented by sediments of Ebinur Lake in arid central Asia. J. Limnol. 2017, 76, 534-545. [CrossRef]

23. Liu, W.; Wu, J.; Ma, L.; Zeng, H. A 200-year sediment record of environmental change from Lake Sayram, Tianshan Mountains in China. GFF 2014, 136, 548-555. [CrossRef]

24. Liu, W.; Wu, J.; Pan, X. A 100-year record of climate change and human activities inferred from the geochemical composition of sediments in Chaiwopu Lake, arid northwest China. J. Limnol. 2016, 75, 297-304. [CrossRef]

25. Chen, F.; Yu, Z.; Yang, M.; Ito, E.; Wang, S.; Madsen, D.B.; Huang, X.; Zhao, Y.; Sato, T.; Birks, J.B.; et al. Holocene moisture evolution in arid central Asia and its out-of-phase relationship with Asian monsoon history. Quat. Sci. Rev. 2008, 27, 351-364. [CrossRef]

26. Wünnemann, B.; Mischke, S.; Chen, F. A Holocene sedimentary record from Bosten Lake, China. Palaeogeogr. Palaeoclimatol. Palaeoecol. 2006, 234, 223-238. [CrossRef] 
27. Zhang, G.; Xie, H.; Yao, T.; Kang, S. Water balance estimates of ten greatest lakes in China using ICESat and Landsat data. Chin. Sci. Bull. 2013, 58, 3815-3829. [CrossRef]

28. Guo, M.; Wu, W.; Zhou, X.; Chen, Y.; Li, J. Investigation of the dramatic changes in lake level of the Bosten Lake in northwestern China. Theor. Appl. Climatol. 2015, 119, 341-351. [CrossRef]

29. Zuo, Q.; Dou, M.; Chen, X.I.; Zhou, K. Physically-based model for studying the salinization of Bosten Lake in China. Hydrol. Sci. J. 2006, 51, 432-449. [CrossRef]

30. Wang, X.; Gong, P.; Zhao, Y.; Xu, Y.; Cheng, X.; Niu, Z.; Luo, Z.; Huang, H.; Sun, F.; Li, X. Water-level changes in China's large lakes determined from ICESat/GLAS data. Remote Sens. Environ. 2013, 132, 131-144. [CrossRef]

31. Rusuli, Y.; Li, L.; Ahmad, S.; Zhao, X. Dynamics model to simulate water and salt balance of Bosten Lake in Xinjiang, China. Environ. Earth Sci. 2015, 74, 2499-2510. [CrossRef]

32. Xiao, M.; Wu, F.; Liao, H.; Li, W.; Lee, X.; Huang, R. Characteristics and distribution of low molecular weight organic acids in the sediment porewaters in Bosten Lake, China. J. Environ. Sci. 2010, 22, 328-337. [CrossRef]

33. Zhang, C.; Mischke, S.; Zheng, M.; Prokopenko, A.; Guo, F.; Feng, Z. Carbon and Oxygen Isotopic Composition of Surface-Sediment Carbonate in Bosten Lake (Xinjiang, China) and its Controlling Factors. Acta Geol. Sin. 2009, 83, 386-395. [CrossRef]

34. Lei, X.; Lu, J.; Liu, Z.; Tong, Y.; Li, S. Concentration and distribution of antibiotics in water-sediment system of Bosten Lake, Xinjiang. Environ. Sci. Pollut. Res. 2015, 22, 1670-1678. [CrossRef]

35. Liu, Y.; Mu, S.; Bao, A.; Zhang, D.; Pan, X. Effects of salinity and (an)ions on arsenic behavior in sediment of Bosten Lake, Northwest China. Environ. Earth Sci. 2015, 73, 4707-4716. [CrossRef]

36. Chen, J.; Zhang, E.; Brooks, S.J.; Huang, X.; Wang, H.; Liu, J.; Chen, F. Relationships between chironomids and water depth in Bosten Lake, Xinjiang, northwest China. J. Paleolimnol. 2014, 51, 313-323. [CrossRef]

37. Huang, X.Z.; Chen, F.H.; Fan, Y.X.; Yang, M.L. Dry late-glacial and early Holocene climate in arid central Asia indicated by lithological and palynological evidence from Bosten Lake, China. Quat. Int. 2009, 194, 19-27. [CrossRef]

38. Mischke, S.; Wünnemann, B. The Holocene salinity history of Bosten Lake (Xinjiang, China) inferred from ostracod species assemblages and shell chemistry: Possible palaeoclimatic implications. Quat. Int. 2006, 154, 100-112. [CrossRef]

39. Yu, Z.; Wang, X.; Fan, H. Spatial Distribution of Organic Carbon in Surface Sediment of Bosten Lake. In Carbon Cycle in the Changing Arid Land of China: Yanqi Basin and Bosten Lake; Wang, X., Yu, Z., Wang, J., Zhang, J., Eds.; Springer: Singapore, 2018; pp. 103-115. [CrossRef]

40. Yu, Z.; Wang, X.; Zhao, C.; Lan, H. Carbon burial in Bosten Lake over the past century: Impacts of climate change and human activity. Chem. Geol. 2015, 419, 132-141. [CrossRef]

41. Wurtsbaugh, W.A.; Miller, C.; Null, S.E.; DeRose, R.J.; Wilcock, P.; Hahnenberger, M.; Howe, F.; Moore, J. Decline of the world's saline lakes. Nat. Geosci. 2017, 10, 816. [CrossRef]

42. Wu, J.; Ma, L.; Zeng, H. Water Quality and Quantity Characteristics and Its Evolution in Lake Bosten, Xinjiang over the Past 50 Years. Sci. Geogr. Sin. 2013, 33, 231-237. [CrossRef]

43. Salamat, A.U.; Abuduwaili, J.; Shaidyldaeva, N. Impact of climate change on water level fluctuation of Issyk-Kul Lake. Arab. J. Geosci. 2015, 8, 5361-5371. [CrossRef]

44. Ma, L.; Wu, J.; Liu, W.; Abuduwaili, J. Distinguishing between anthropogenic and climatic impacts on lake size: A modeling approach using data from Ebinur Lake in arid northwest China. J. Limnol. 2014, 73, 148-155. [CrossRef]

45. Chen, F.; Huang, X.; Zhang, J.; Holmes, J.A.; Chen, J. Humid Little Ice Age in arid central Asia documented by Bosten Lake, Xinjiang, China. Sci. China Ser. D Earth Sci. 2006, 49, 1280-1290. [CrossRef]

46. Zhang, J.; Zhou, C.; Li, J. Spatial pattern and evolution of oases in the Yanqi Basin, Xinjiang. Geogr. Res. 2006, 25, 350-358. [CrossRef]

47. Huang, T.; Pang, Z. Changes in groundwater induced by water diversion in the Lower Tarim River, Xinjiang Uygur, NW China: Evidence from environmental isotopes and water chemistry. J. Hydrol. 2010, 387, 188-201. [CrossRef]

48. Wu, J.; Liu, W.; Zeng, H.; Ma, L.; Bai, R. Water Quantity and Quality of Six Lakes in the Arid Xinjiang Region, NW China. Environ. Process. 2014, 1, 115-125. [CrossRef]

49. Zhou, H.; Chen, Y.; Perry, L.; Li, W. Implications of climate change for water management of an arid inland lake in Northwest China. Lake Reserv. Manag. 2015, 31, 202-213. [CrossRef] 
50. Yu, Z.; Wang, X.; Chengyi, Z.; Haiyan, L.A.N. Source characterization of organic carbon using elemental, isotopic and n-alkanes proxies in surface sediment from Lake Bosten, Xinjiang. J. Lake Sci. 2015, 27, 983-990. [CrossRef]

51. Palma, P.; Ledo, L.; Alvarenga, P. Assessment of trace element pollution and its environmental risk to freshwater sediments influenced by anthropogenic contributions: The case study of Alqueva reservoir (Guadiana Basin). Catena 2015, 128, 174-184. [CrossRef]

52. Shen, J.; Liu, X.; Wang, S.; Ryo, M. Palaeoclimatic changes in the Qinghai Lake area during the last 18,000 years. Quat. Int. 2005, 136, 131-140. [CrossRef]

53. Ermakhanov, Z.K.; Plotnikov, I.S.; Aladin, N.V.; Micklin, P. Changes in the Aral Sea ichthyofauna and fishery during the period of ecological crisis. Lakes Reserv. Res. Manag. 2012, 17, 3-9. [CrossRef]

54. Shibuo, Y.; Jarsjö, J.; Destouni, G. Hydrological responses to climate change and irrigation in the Aral Sea drainage basin. Geophys. Res. Lett. 2007, 34. [CrossRef]

55. Yao, J.; Chen, Y.; Zhao, Y.; Yu, X. Hydroclimatic changes of Lake Bosten in Northwest China during the last decades. Sci. Rep. 2018, 8, 9118. [CrossRef]

56. Glantz, M. Creeping Environmental Problems and Sustainable Development in the Aral Sea Basin; Cambridge University Press: Cambridge, UK, 1999.

57. Liu, W.; Abuduwaili, A.; Ma, L. Geochemistry of major and trace elements and their environmental significances in core sediments from Bosten Lake, arid northwestern China. J. Limnol. 2019, 78, 201-209. [CrossRef]

58. Appleby, P.G. Three decades of dating recent sediments by fallout radionuclides: A review. Holocene 2008, 18, 83-93. [CrossRef]

59. Pennington, W.; Tutin, T.G.; Cambray, R.S.; Fisher, E.M. Observations on lake sediments using fallout 137Cs as a tracer. Nature 1973, 242, 324. [CrossRef]

60. Meyers, P.A.; Ishiwatari, R. Lacustrine organic geochemistry-An overview of indicators of organic matter sources and diagenesis in lake sediments. Org. Geochem. 1993, 20, 867-900. [CrossRef]

61. Teranes, J.L.; Bernasconi, S.M. The record of nitrate utilization and productivity limitation provided by $\delta 15 \mathrm{~N}$ values in lake organic matter-A study of sediment trap and core sediments from Baldeggersee, Switzerland. Limnol. Oceanogr. 2000, 45, 801-813. [CrossRef]

62. Meyers, P.A.; Lallier-Vergés, E. Lacustrine Sedimentary Organic Matter Records of Late Quaternary Paleoclimates. J. Paleolimnol. 1999, 21, 345-372. [CrossRef]

63. Contreras, S.; Werne, J.P.; Araneda, A.; Urrutia, R.; Conejero, C.A. Organic matter geochemical signatures (TOC, TN, C/N ratio, $\delta 13 \mathrm{C}$ and $\delta 15 \mathrm{~N}$ ) of surface sediment from lakes distributed along a climatological gradient on the western side of the southern Andes. Sci. Total Environ. 2018, 630, 878-888. [CrossRef] [PubMed]

64. Kumar, A.; Hage-Hassan, J.; Baskaran, M.; Miller, C.J.; Selegean, J.P.; Creech, C.T. Multiple sediment cores from reservoirs are needed to reconstruct recent watershed changes from stable isotopes $(\delta 13 \mathrm{C}$ and $\delta 15 \mathrm{~N})$ and $\mathrm{C} / \mathrm{N}$ ratios: Case studies from the mid-western United States. J. Paleolimnol. 2016, 56, 15-31. [CrossRef]

65. Xu, H.; Ai, L.; Tan, L.; An, Z. Stable isotopes in bulk carbonates and organic matter in recent sediments of Lake Qinghai and their climatic implications. Chem. Geol. 2006, 235, 262-275. [CrossRef]

66. Meyers, P.A.; Teranes, J.L. Sediment Organic Matter. In Tracking Environmental Change Using Lake Sediments: Physical and Geochemical Methods; Last, W.M., Smol, J.P., Eds.; Springer: Dordrecht, The Netherlands, 2001; pp. 239-269. [CrossRef]

67. Fan, J.; Xiao, J.; Wen, R.; Zhang, S.; Wang, X.; Cui, L.; Yamagata, H. Carbon and nitrogen signatures of sedimentary organic matter from Dali Lake in Inner Mongolia: Implications for Holocene hydrological and ecological variations in the East Asian summer monsoon margin. Quat. Int. 2017, 452, 65-78. [CrossRef]

68. Varrica, D.; Aiuppa, A.; Dongarrà, G. Volcanic and anthropogenic contribution to heavy metal content in lichens from Mt. Etna and Vulcano island (Sicily). Environ. Pollut. 2000, 108, 153-162. [CrossRef]

69. Chakraborty, S.; Bhattacharya, T.; Singh, G.; Maity, J.P. Benthic macroalgae as biological indicators of heavy metal pollution in the marine environments: A biomonitoring approach for pollution assessment. Ecotoxicol. Environ. Saf. 2014, 100, 61-68. [CrossRef]

70. Ma, L.; Abuduwaili, J.; Li, Y.; Ge, Y. Controlling Factors and Pollution Assessment of Potentially Toxic Elements in Topsoils of the Issyk-Kul Lake Region, Central Asia. Soil Sediment Contam. Int. J. 2018, 27, 147-160. [CrossRef] 
71. Massakbayeva, A.; Abuduwaili, J.; Issanova, G.; Bissenbayeva, S.; Issina, B. Temperature and Precipitation Trend in The Aral Sea and Aral Sea Region During 1960-2016. Bull. Natl. Acad. Sci. Repub. Kaz. 2019, 3, 6-15. [CrossRef]

72. Ma, L.; Wu, J.; Abuduwaili, J. The climatic and hydrological changes and environmental responses recorded in lake sediments of Xinjiang, China. J. Arid Land 2011, 3, 1-8. [CrossRef]

73. Gaybullaev, B.; Chen, S.C.; Gaybullaev, G. The large Aral Sea water balance: A future prospective of the large Aral Sea depending on water volume alteration. Carbonates Evaporites 2014, 29, 211-219. [CrossRef]

74. Gong, X.L.; Cui, Z.K.; Zhang, X.Y.; Wang, C.H. Complete mitochondrial DNA sequence of the endangered Tarim schizothoracin (Schizothorax biddulphi Günther). Mitochondrial DNA 2012, 23, 385-387. [CrossRef] [PubMed]

75. Micklin, P. Aral Sea Basin Water Resources and the Changing Aral Water Balance. In The Aral Sea: The Devastation and Partial Rehabilitation of a Great Lake; Micklin, P., Aladin, N.V., Plotnikov, I., Eds.; Springer: Berlin/Heidelberg, Germany, 2014; pp. 111-135. [CrossRef]

76. Micklin, P. The future Aral Sea: Hope and despair. Environ. Earth Sci. 2016, 75, 844. [CrossRef]

77. Breckle, S.W.; Geldyeva, G.V. Dynamics of the Aral Sea in Geological and Historical Times. In Aralkum-A Man-Made Desert: The Desiccated Floor of the Aral Sea (Central Asia); Breckle, S.-W., Wucherer, W., Dimeyeva, L.A., Ogar, N.P., Eds.; Springer: Berlin/Heidelberg, Germany, 2012; pp. 13-35. [CrossRef]

78. Pala, C. Once a Terminal Case, the North Aral Sea Shows New Signs of Life. Science 2006, 312, 183. [CrossRef] [PubMed]

79. Shen, H.; Abuduwaili, J.; Ma, L.; Samat, A. Remote sensing-based land surface change identification and prediction in the Aral Sea bed, Central Asia. Int. J. Environ. Sci. Technol. 2018. [CrossRef]

(C) 2020 by the authors. Licensee MDPI, Basel, Switzerland. This article is an open access article distributed under the terms and conditions of the Creative Commons Attribution (CC BY) license (http://creativecommons.org/licenses/by/4.0/). 